\title{
Regional State-Supported Agricultural Insurance Development in Context of Global Transformations
}

\author{
Ekaterina A. Shkarupa \\ Volgograd State University \\ Economics and Finance Institute \\ Volgograd, Russia \\ shkarupaea@volsu.ru
}

\author{
Pavel P. Perehodov \\ Volgograd State University \\ Economics and Finance Institute \\ Volgograd, Russia \\ perehodovPP@volsu.ru
}

\author{
Irina A. Ulanova \\ Volgograd State Agricultural University \\ Ecology and Melioration Faculty \\ Volgograd, Russia \\ irina301170@yandex.ru
}

\begin{abstract}
Improving the competitiveness of the country and regions' agriculture is a solution to the problems of its further development. It should be noted that a sustainable and stable development of agriculture can be achieved only through the government support measures implementation. Insurance premiums State subsidization is the financial instrument, which does not contradict the World Trade Organization requirements. At present, the State-supported agricultural insurance conditions do not provide adequate interest among agricultural producers. The article is devoted to consideration of major aspects of agricultural insurance in the context of global transformations. We determined the reducing demand for Statesupported agricultural insurance and made an attempt to systematize the causes behind this phenomenon. The study of indicators of agricultural insurance in the Volgograd region was carried out using time series analysis. Special attention is given to a new instrument in agricultural insurance such as a "unified" subsidy. The result of destabilizing conditions in the organization of the system of agricultural insurance in the context of granting subsidies was a radical deterioration in the market. The unadapted subsidy system has resulted in substantial agricultural insurance volumes fall. The main problems in the allocation of subsidies from the federal budget to the regions are identified. We have considered a plausible course of agricultural insurance development.
\end{abstract}

Keywords - unified subsidy, food security, agricultural insurance, agricultural commodity producer, indemnity insurance, insurance contributions, government subsidization, financial instrument

\section{INTRODUCTION}

At the last Food and Agriculture Organization of the United Nations (FAO) Summit in 2002, the global nature of the food problem has been recognized.

The special role of agriculture in the regions' food security and their competitiveness increase require a financial security corresponding to global challenges.
In Russia, the Doctrine of Food Security of the Russian Federation was adopted. Some points of the doctrine focus on improving the efficiency of the state financial control and support of agricultural commodity producers, creating conditions to maintain their financial stability and capacity to pay [1].

Russia's joining the World Trade Organization (hereinafter - the WTO) makes it relevant to address matters regarding public financial support of agricultural commodity producers in the aspect of basic agreements, principles, norms, and rules of the international organization. State-supported agricultural insurance (hereinafter - the agricultural insurance) is one of the imperatives of financial policy in the development of agriculture, which does not contradict the WTO requirements. These measures are not related to the agricultural products prices formation; and they are included in the "green box". Therefore, the agricultural insurance development is rational, urgency and need-driven by the "unified subsidy" introduction.

Such authors as V.I. Nazarenko [2], A.G. Paptsov [3], N.I. Shagaida, V.Ya. Uzun [4], I.G. Ushachev [5], and others were engaged in studying the global facets of food safety. The various aspects of agricultural insurance problems are reflected in the works of Russian researchers, for instance, T.P. Lomakina [6], Y.N. Parahin [7], and others. O.K. Kotar has considered the peculiarities of State-supported agricultural insurance in Russia in the context of globalization [8]. It must be noted that in the Russian economic science there are no publications devoted to studying regional agricultural insurance in connection with the introduction of "unified subsidy".

The purpose of the study is to propose recommendations for the development of agricultural insurance to expand its scale, improve accessibility and ensure the competitiveness of countries and regions. 
Achieving the goal determined the following objectives: 1) review the current state and problems of agricultural insurance in the Russian Federation and the Volgograd region; 2) suggest plausible agricultural insurance development course in the context of globalization.

\section{MATERIALS AND Methods (MODEL)}

The study's regulatory framework is based on the normative documents and legal regulation of the agricultural insurance system.

Information and empirical basis of the research consists of official statistical materials of the Ministry of Agriculture of the Russian Federation, the Union of " United Insurers of Agro-Industrial Complex - the National Union of AgroInsurers", the Federal Agency of State support for the agroindustrial complex; analytical reviews published in the periodical press and the Internet.

The article is based on the study and synthesis of theoretical and empirical agricultural insurance data. There were such methods used: systematic and comparative ones, analysis of time series, as well as table and graphical methods of data processing and its presentation.

\section{RESULTS AND DISCUSSION}

Agricultural insurance is carried out according to the Federal Law № 260-FZ "On State Support of Agricultural Insurance and on Introduction of Amendments to the Federal Law "On Development of Agricultural Sector", which establishes general conditions and rules for government agricultural insurance subsidies granting [9].

Agricultural insurance is currently characterized by a small percentage of insured areas of agricultural crops and perennial plantings.

Figure 1 shows the ratio of the gross sown area of agricultural crops and sown area of agricultural crops under State-supported insurance cover. Since 2012, there has been a decrease in the insured agricultural land nearly 3,5 times (from 12,9 million hectares to 3,8 million hectares).

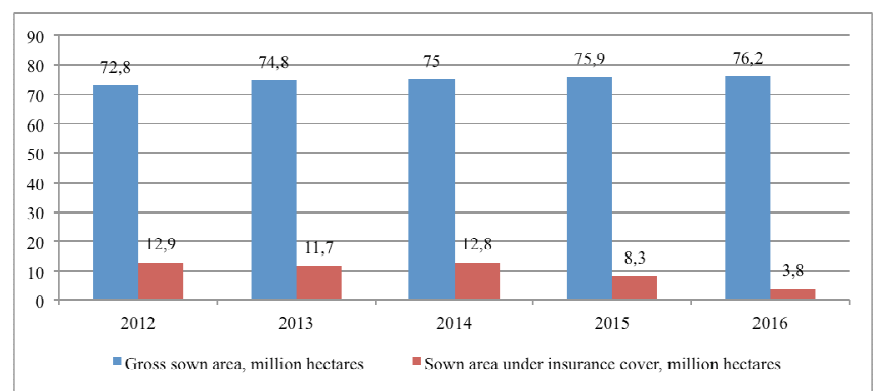

Fig. 1. The ratio of gross sown area of agricultural crops and sown area of agricultural crops under State-supported insurance cover, million hectares (conducted by the authors according to [10])

In our opinion, the main reason for this fact is a decline in demand for agricultural insurance.
Thus, the uncertainty of agricultural producers in obtaining insurance compensation on the harvest loss (lower payments of insurance compensation in the previous years) becomes a demotivating factor in the need for agricultural risks insurance. Also, there are long-term court cases and cases of insured accidents simulation by agricultural producers. The latter is due to a dissatisfaction of agricultural commodity producers with the loss harvest criterion for recognition of an insured event (more than 30\%) [9].

Because of their adverse financial situation, the majority of agricultural commodity producers cannot use the services of insurance companies. This is due to the need for the insurance premiums to be paid, which requires funds that agricultural commodity producers have to draw during a sowing season.

Within the analyzed period (from 2012 to 2016) there has been a reduction in the number of subjects participating in agricultural insurance (from 60 to 42). Heterogeneity can be observed in the reduction of the number of insurance companies participating in insurance (see Fig. 2).

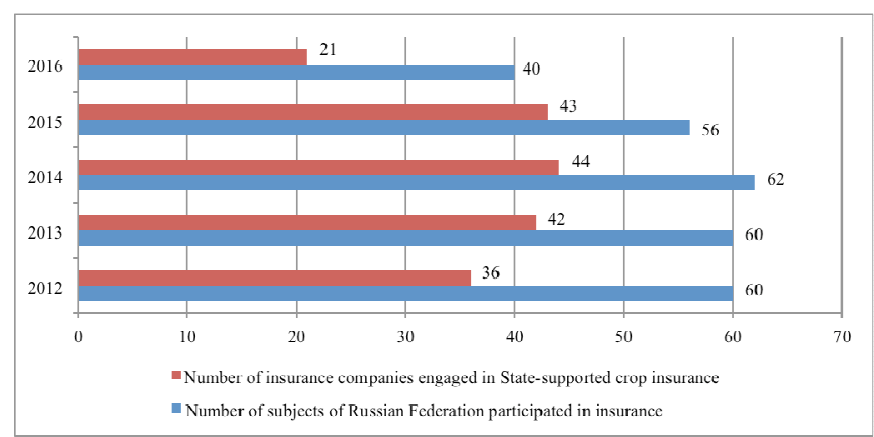

Fig. 2. Number of Subjects of Russian Federation, which had StateInsurance Contracts on Crop and Perennial Plants and Number of Insurance Companies, which Concluded Insurance Contracts between 2012 and 2016, units (conducted by the authors according to [10])

Particularly, in 2016 the reasons for a 52\% reduction of insurance companies were the changes in the Russian legislation in the aspect of their activities regulation. The condition of membership in the National Union of AgroInsurers (hereinafter - NUA) is mandatory for insurance companies entering State-supported agro-insurance contracts [11]. NUA is open to new members, but the conditions written in the Rules of the Union, for many are impossible or undesirable.

Recovery of the agricultural insurance market with the Central Bank's actions has also caused an insurance companies licenses revocation. Thus, between 2015-2016 it resulted in a termination of activities of 28 insurance companies, in which $57,2 \%$ of all insured areas were insured in 2015 [12].

The decline in the number of insurance companies in the Russian regions tends to reduce competition in the market, hence, it leads to deterioration of the quality and service conditions in this area. High insurance rates, failing to take into account region's peculiarities, reduction of insurance indemnity payments also hinder the agricultural insurance development. 
Analyzing time-series, we carried out an assessment of agricultural insurance in the Volgograd region on the basis of available statistical data (from 2013 to 2016). Time-series analysis includes the following parameters: growth rate, percent change, amount of change, absolute value of $1 \%$ growth, rate of increase.

\section{Growth rate (in \% to base year)}

$$
T_{g b}=\frac{x_{i}}{x_{0}} \square 00 \%
$$

where

$x_{i}$ - current (comparable) year amount;

$x_{0}$ - base year amount.

Growth rate (in \% to previous year)

$$
T_{g p}=\frac{X_{i}}{X_{i-1}} \square 00 \%
$$

where

$x_{i}$ - current (comparable) year amount;

$x_{i-1}$ amount prior to current year.

Percent change (in \% to base year)

$$
T_{p c b}=\frac{\Delta x_{b}}{x_{0}} \square 100 \%=\frac{x_{i}-x_{0}}{x_{0}} \square 100 \%
$$

where

$\Delta x_{b}$ - amount of change (current year amount minus base year amount).

Percent change (in \% to previous year)

$$
T_{p c p}=\frac{\Delta X_{p}}{X_{i-1}} \square 100 \%=\frac{X_{i}-X_{i-1}}{X_{i-1}} \square 00 \%
$$

where

$\Delta x_{p}$ - amount of change (current year amount minus previous year amount).

\section{Absolute value of $1 \%$ growth}

$$
A \%=\frac{\Delta x_{p}}{T_{p c p, \%}}=0,01 \square x_{i-1}
$$

Rate of increase (amount of change to previous year divided by base year amount)

$$
T_{i n}=\frac{\Delta X_{p}}{X_{0}}
$$

Statistical data analysis presented in Table 1 showed the following: growth rates of almost all indicators are less than $100 \%$. It indicates the negative dynamics of agricultural insurance development.

There is positive dynamics of the gross sown area $(6,9 \%$ increase or 109,8 thousand hectares in relation to 2013), the indicators of a sown area under insurance cover significantly decreased (by $86,9 \%$ or 494,9 thousand hectares in relation to 2013). The rate of increase of the last indicator shows that there is a decreasing trend in the series, what, in our opinion, once again proves a decline in the agricultural insurance demand (see Table. 1, see Fig. 3).

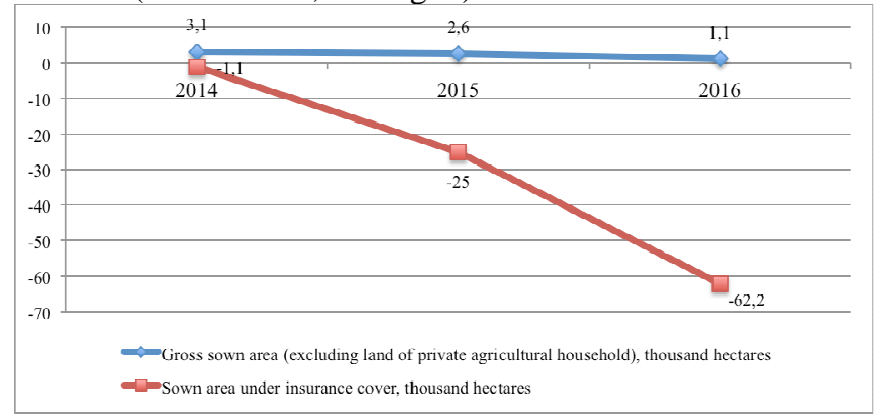

Fig. 3. Rates of increase of sown area and sown area under insurance cover indicators, $\%$ (conducted by the authors based on the research)

It is difficult to predict further development of the agricultural insurance market due to the global challenges. First of all, there is no systematic data on insurance of agricultural crops and perennial plantings in 2017. Secondly, since 2017 the novel course of state support for agriculture was to contribute to the achievement of the regional agriculture development programs targets ("unified subsidy") [12]. Government spending on agricultural insurance became a part of the "unified subsidy". Its funds are allocated from the federal budget to the regions; then a region is empowered to self-distribution of such subsidies.

The "unified subsidy" introduction has aggravated the already difficult situation of agricultural insurance. Lack of transparency and confidence among agricultural commodity producers in obtaining subsidies caused the decline in contracts, as their absence does not change the duty of the insurer to pay the insurance premium in full. The unavailability of the regulatory framework, unresolved order of budget allocations determine the risk of delays in obtaining subsidies for agricultural insurance. With the transition to a "unified subsidy", in copious regions there were no means to compensate agricultural commodity producers' expenses for paying premiums under the harvest insurance contract.

According to the NUA, in 2017 there was a decrease of indicators of sown areas insurance coverage even in those regions that in 2016 showed a high demand for agricultural insurance; 17 agricultural regions have declared a state of emergency [11]. 
TABLE I. TIME-SERIES ANALYSIS OF STATE-SUPPORTED AGRICULTURAL CROPS AND PERENNIAL PLANTINGS INSURANCE BETWEEN 2012-2016 IN VOLGOGRAD REGION

\begin{tabular}{|c|c|c|c|c|c|c|c|c|}
\hline 2013 & 2014 & 2015 & 2016 & \multirow[b]{2}{*}{ Indicator name $^{\mathrm{a}}$} & 2013 & 2014 & 2015 & 2016 \\
\hline \multicolumn{4}{|c|}{ Number of entities concluded insurance agreements to be subsidized } & & \multicolumn{4}{|c|}{$\begin{array}{c}\text { Number of concluded and accepted to be subsidized insurance } \\
\text { agreements }\end{array}$} \\
\hline 127 & 191 & 100 & 18 & units & 238 & 211 & 147 & 19 \\
\hline 100 & 150,4 & 78,8 & 14,2 & $\mathrm{~T}_{\mathrm{gb}}, \%$ & 100 & 88,6 & 61,8 & 8 \\
\hline 100 & 150,4 & 52,4 & 18 & $\mathrm{~T}_{\mathrm{gp}}, \%$ & 100 & 88,6 & 69,7 & 12,3 \\
\hline- & 50,4 & $-21,2$ & $\begin{array}{l}-85,8 \\
\end{array}$ & $\mathrm{~T}_{\mathrm{pcb}}, \%$ & - & $-11,4$ & $-38,2$ & -92 \\
\hline- & 50,4 & $-47,6$ & -84 & $\mathrm{~T}_{\mathrm{pcp}}, \%$ & - & $-11,4$ & $-30,3$ & $-87,7$ \\
\hline- & 64 & -27 & -109 & $A_{b}$, units & - & -27 & -91 & -219 \\
\hline - & 64 & -91 & -82 & $A_{p}$, units & - & -27 & -64 & -128 \\
\hline- & 1,27 & 1,9 & 0,9 & A\% & - & 2,3 & 2,1 & 1,5 \\
\hline- & 5,03 & $-71,6$ & $-64,5$ & $\mathrm{~T}_{\mathrm{in}}, \%$ & - & $-11,7$ & $-27,8$ & $-55,6$ \\
\hline \multicolumn{5}{|c|}{ Gross sown area (excluding land of private agricultural household) } & \multicolumn{4}{|c|}{ Sown area under insurance cover } \\
\hline 2772,02 & 2858,95 & 2931,6 & 2962,8 & thous. ha. & 569,622 & 563,398 & 423,1 & 74,7 \\
\hline 100 & 103,1 & 105,7 & 106,9 & $\mathrm{~T}_{\mathrm{p} \sigma}, \%$ & 100 & 98,9 & 74,2 & 13,1 \\
\hline 100 & 103,1 & 102,5 & 101,7 & $\mathrm{~T}_{\mathrm{p}}, \%$ & 100 & 98,9 & 75,1 & 17,7 \\
\hline- & $+3,1$ & $+5,7$ & $+6,9$ & $\mathrm{~T}_{\mathrm{n} 6}, \%$ & - & $-1,1$ & $-25,8$ & $-86,9$ \\
\hline- & $+3,1$ & $+2,5$ & $+1,7$ & $\mathrm{~T}_{\mathrm{nщ}}, \%$ & - & $-1,1$ & $-24,9$ & $-82,3$ \\
\hline- & 86,9 & 159,6 & 190,8 & 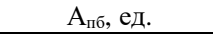 & - & $-6,2$ & $-146,5$ & $-494,9$ \\
\hline- & 86,9 & 72,6 & 31,2 & $\mathrm{~A}_{\text {пц }}$ ед. & - & $-6,2$ & $-140,3$ & $-348,4$ \\
\hline- & 28 & 29 & 18,3 & $\mathrm{~A} \%$ & - & 5,6 & $-5,6$ & $-4,2$ \\
\hline- & 3,1 & 2,6 & 1,1 & $\mathrm{~T}_{\mathrm{H}}, \%$ & - & $-1,1$ & -25 & $-62,2$ \\
\hline \multicolumn{4}{|c|}{ Sum insured } & & \multicolumn{4}{|c|}{ Assessment sum of insurance premium (insurance contribution) } \\
\hline 7554457 & 7074846 & 5482019 & 1543513 & thous. rub. & 518000 & 492514 & 377341 & 32471 \\
\hline 100 & 93,6 & 72,6 & 20,4 & $\mathrm{~T}_{\mathrm{gb}}, \%$ & 100 & 95,1 & 72,9 & 6,3 \\
\hline 100 & 93,6 & 77,5 & 28,1 & $\mathrm{~T}_{\mathrm{gp}}, \%$ & 100 & 95,1 & 76,7 & 8,6 \\
\hline- & $-6,4$ & $-27,4$ & $-79,6$ & $\mathrm{~T}_{\mathrm{pcb}}, \%$ & - & $-4,9$ & $-27,1$ & $-93,7$ \\
\hline - & $-6,4$ & $-22,5$ & $-71,9$ & $\mathrm{~T}_{\mathrm{pcp}}, \%$ & - & $-4,9$ & $-23,3$ & $-91,4$ \\
\hline- & $\begin{array}{r}-479611 \\
\end{array}$ & -2072438 & -6010944 & $\mathrm{~A}_{\mathrm{b}}$, units & - & -25486 & -140659 & -485529 \\
\hline- & $\begin{array}{l}-479611 \\
\end{array}$ & -1592827 & -3938506 & $A_{p}$, units & - & -25486 & -115173 & -344870 \\
\hline- & 74939,2 & 70792,3 & 54777,5 & $\mathrm{~A} \%$ & - & 5201,2 & 4943 & 3773, \\
\hline- & $-6,4$ & $-21,2$ & $-52,5$ & $\mathrm{~T}_{\mathrm{in}}, \%$ & - & $-4,9$ & $-22,1$ & 66,3 \\
\hline \multicolumn{4}{|c|}{ Paid sum of insurance contributions } & & \multicolumn{4}{|c|}{$\begin{array}{c}\text { Subsidies granted to agricultural commodity producers from federa } \\
\text { budget of the Russian Federation }\end{array}$} \\
\hline 516857 & 456085 & 271756 & 32471 & thous. rub. & 245346,4 & 204003,4 & 53877,1 & 15423,9 \\
\hline 100 & 88,2 & 52,6 & 6,2 & $\mathrm{~T}_{\mathrm{gb}}, \%$ & 100 & 83,1 & 21,9 & 6,3 \\
\hline 100 & 88,2 & 59,6 & 12 & $\mathrm{~T}_{\mathrm{gp}}, \%$ & 100 & 83,1 & 26,4 & 28,6 \\
\hline- & $-11,8$ & $-47,4$ & $-93,8$ & $\mathrm{~T}_{\mathrm{pcb}}, \%$ & - & $-16,9$ & $-78,1$ & $-93,7$ \\
\hline- & $-11,8$ & $-40,4$ & -88 & $\mathrm{~T}_{\mathrm{pcp}}, \%$ & - & $-16,9$ & $-73,6$ & $-71,4$ \\
\hline- & -60772 & -245101 & -484386 & $A_{b}$, units & - & -41343 & $-191469,3$ & $-229922,5$ \\
\hline- & -60772 & -184329 & -239285 & $A_{p}$, units & - & -41343 & $-150126,3$ & $-38453,2$ \\
\hline- & 5150,2 & 4562,6 & 2719,5 & $\mathrm{~A} \%$ & - & 2446,3 & 2039,8 & 538,6 \\
\hline- & $-11,8$ & $-35,8$ & $-46,5$ & $\mathrm{~T}_{\mathrm{in}}, \%$ & - & $-16,9$ & $\begin{array}{l}-61,4 \\
\end{array}$ & $-15,7$ \\
\hline \multicolumn{4}{|c|}{$\begin{array}{c}\text { Subsidies granted to agricultural commodity producers from budgets } \\
\text { of the Russian Federation entities }\end{array}$} & & \multicolumn{4}{|c|}{ Insurance indemnity amount } \\
\hline 30833,8 & 10627,5 & 32000,0 & 811,8 & thous. rub. & 10269 & 51715 & 3800 & - \\
\hline 100 & 34,5 & 103,8 & 2,6 & $\mathrm{~T}_{\mathrm{gb}}, \%$ & 100 & 503,6 & 37 & - \\
\hline 100 & 34,5 & 301,1 & 2,5 & $\mathrm{~T}_{\mathrm{gp}}, \%$ & 100 & 503,6 & 7,3 & - \\
\hline- & $-65,5$ & $+3,8$ & $-97,4$ & $\mathrm{~T}_{\mathrm{pcb}}, \%$ & - & 403,6 & -63 & - \\
\hline- & $\begin{array}{l}-65,5 \\
\end{array}$ & $+201,1$ & $-97,5$ & $\mathrm{~T}_{\mathrm{pcp}}, \%$ & - & 403,6 & 92,7 & - \\
\hline- & $-20206,3$ & 1166,2 & $-30,022$ & $A_{b}$, units & - & 41446 & -6469 & - \\
\hline - & $-20206,3$ & 21372,5 & $-31188,2$ & $A_{p}$, units & - & 41446 & -47915 & - \\
\hline- & 308,5 & 106,3 & 319,9 & A\% & - & 102,7 & $-516,9$ & - \\
\hline- & $-65,5$ & 69,3 & -101 & $\mathrm{~T}_{\mathrm{in}}, \%$ & - & 403,5 & $-466,5$ & - \\
\hline
\end{tabular}

${ }^{\text {a. }} \mathrm{T}_{\mathrm{gb}}$ - Growth rate (to base year), $\mathrm{T}_{\mathrm{gp}}$ - Growth rate (to previous year), $\mathrm{T}_{\mathrm{pcb}}$ - Percent change (to base year), $\mathrm{T}_{\mathrm{pcp}}$ - Percent change (to previous year), $A_{b-}$ Amount of change (to base year), $A_{p}$. Amount of change (to previous year), $A \%$ - Absolute value of $1 \%$ growth, $T_{i n}-$ Rate of increase

An agricultural insurance segment showed the maximum rate of decrease in premiums. As a result of changes in subsidy conditions and delays in the adoption of necessary bylaws, during the year total premiums fell more than 2 times to 3,18 billion rubles, while the volume of insurance - more than 3 times from 6,4 billion to 2,1 billion rubles [13].

\section{CONCLUSION}

Analysis of Russia and Volgograd region's agricultural insurance development confirmed the reduction in agricultural commodity producers' insurance activity. 
The "unified subsidy" has contributed to the reasons, which lead to the phenomenon, such as an unstable financial position of agricultural commodity producers, high insurance rates, uncertainty of obtaining insurance indemnity, low literacy on insurance programs. The "unified subsidy" introduction in the regions can be described as an unpredictable tool of financial compensation for agricultural producers' losses, occurring as a result of the insured event. A payment for its occurrence is carried out as a residual or not performed at all.

Therefore, as an agricultural insurance development basis, there should be a mutual interest between agricultural insurance entities: for agricultural commodity producers - a guarantee, timely receipt of funds, and protection of agricultural production; for the state - a reduction in payments to compensate for losses from natural disasters; insurers sustainable business development.

Guarantee of insurance payments receipt in case of an insured event provides the basis for the expansion of agricultural insurance. According to the results of the study, we suggest the following agricultural insurance development course.

It is necessary to attract more insurance companies into regional markets; the presence of independent examination will promote the principle of objectivity and transparency when assessing agricultural producers' damages and losses.

It is advisable to continue to improve the reinsurance system, which will guide the agricultural insurance market development and increase its stability. Considering the difference in the country's climatic conditions, it seems possible to create differentiated insurance conditions for regions of the Russian Federation (insurance zoning).

In our opinion, it is feasible to separate state support of agricultural insurance from "unified subsidy' into a separate direction. However, in the case of its remaining the same way, it is vital to adjust and finalize regulations to ensure inevitability and promptness of the subsidy.

Agricultural insurance development potential is not limited to the proposed directions. The results are not necessarily a complete disclosure of all aspects of agricultural insurance problems.

Recommendations can be a base for increasing agricultural insurance availability and its widespread accessibility.

\section{References}

[1] Decree of the President of the Russian Federation of January 30, 20110 № 120 "On approval of the Doctrine of food security of the Russian Federation" [Ukaz Prezidenta RF ot 30 yanvarya 20110 g.№120 «Ob utverzhdenii Doktriny prodovol'stvennoi bezopasnosti Rossiiskoi Federatsii»]. Available at: http://kremlin.ru/acts/bank/41460

[2] V.I. Nazarenko [V.I. Nazarenko], "Food safety (in the world and in Russia)" [Prodovol'stvennaya bezopasnost' (v mire i v Rossii)]. Moscow: Monuments of historical thought, 2011.

[3] A.G. Paptsov [A.G. Paptsov], "The direction of global food security", AIC: Economics, management [APK: ekonomika, upravlenie], vol.10, pp.103-107, October - 2015.
[4] N.I. Shagaida and V. Ya. Uzun [N.I. Shagaida i V.Ya. Uzun.], "Food security in Russia: monitoring trends and threats" [Prodovol'stvennaya bezopasnost' v Rossii: monitoring, tendentsii i ugrozy]. M.: Publishing house "Delo" Ranepa, 2015.

[5] I. G. Ushachev [I. G. Ushachev] "Problems of ensuring national and collective food security in the conditions of international and regional integration" [Problemy obespecheniya natsional'noi i kollektivnoi prodovol'stvennoi bezopasnosti $\mathrm{v}$ usloviyakh mezhdunarodnoi i regional'noi integratsii], Agricultural machines and technologies [Sel'skokhozyaistvennye mashiny i tekhnologii], vol.5, pp. 7-11, September 2014.

[6] T.P. Lomakina [T.P. Lomakina], "Insurance of future harvest in modern Russia" [Strakhovanie budushchego urozhaya v sovremennoi Rossii]: Monograph. Volgograd: Change, 2001.

[7] Yu. N. Parakhin [Yu.N. Parakhin], "Agricultural producers income insurance Program" [Programma strakhovaniya dokhodov proizvoditelei sel'khozproduktsii], Economy, labor, management in agriculture [Ekonomika, trud, upravlenie v sel'skom khozyaistve], vol. 2 (27), pp. 15-18, June 2011

[8] O. K. Kotar [O.K. Kotar], "Development of agricultural insurance with state support in Russia in the context of globalization" [Razvitie sel'skokhozyaistvennogo strakhovaniya s gosudarstvennoi podderzhkoi v Rossii v usloviyakh globalizatsii']: dissertation, Saratov: [manuscript], 2014 .

[9] On the state support in sphere of agricultural insurance and on introducing amendments to the Federal law "On development of agriculture: Feder. the law Grew. Federation of July 25, 2011 № 260-FZ [O gosudarstvennoi podderzhke $\mathrm{v}$ sfere sel'skokhozyaistvennogo strakhovaniya i o vnesenii izmenenii v Federal'nyi zakon «O razvitii sel'skogo khozyaistva: feder. zakon Ros. Federatsii ot 25 iyulya $2011 \mathrm{~g}$ № 260-FZ]. Available at: http://pravo.gov.ru/proxy/ips/?docbody=\&nd=102149576\&rdk=\&backli $\mathrm{nk}=1$

[10] Statistical data on crop insurance of crops, crops and plantings of perennial plantings and farm animals with state support in 2012-2016 [Statisticheskie dannye po strakhovaniyu urozhaya sel'skokhozyaistvennykh kul'tur, urozhaya i posadok mnogoletnikh nasazhdenii i sel'skokhozyaistvennykh zhivotnykh s gosudarstvennoi podderzhkoi v 2012-2016 gg.]: Information and practical brochure-M.: Federal Agency of state support of agriculture of the Ministry of agriculture of Russia, 2016

[11] Official website of the Union " United Association of insurers of agroindustrial complex - national Union of agricultural insurers» [Ofitsial'nyi sait Soyuza «Edinoe ob"edinenie strakhovshchikov agropromyshlennogo kompleksa - Natsional'nyi soyuz agrostrakhovshchikov»]. Available at: http://www.naai.ru/

[12] Official site of the Ministry of agriculture of the Russian Federation [Ofitsial'nyi sait Ministerstva sel'skogo khozyaistva Rossiiskoi Federatsii]. Available at: http://www.mcx.ru

[13] The insurance market overview for the first 9 months of 2017. The national Rating Agency [Obzor strakhovogo rynka za 9 mesyatsev 2017 goda. Natsional'nyi agentstvo Rating]. Available at: http://www.ranational.ru/sites/default/files/analitic_article

[14] Federal Agency for state support of agroindustrial complex [Federal'noe agentstvo po gosudarstvennoi podderzhke deyatel'nosti agropromyshlennogo kompleksa]. Available at: http://www.fagps.ru/

[15] M.V. Ledeneva , M. V. Parfenova, S. I. Vasilieva, L.V. ShamrayKurbatova "The Effectiveness of the Government Support To Small and Medium-Sized Businesses in the Volgograd Region Including an Innovative Entrepreneurship", International Journal of Advanced Biotechnology and Research, vol. 8, Issue 2, pp. 687-697, 2017

[16] L.V. Popova, N.N. Balashova, T.A. Dugina, N.V. Gorshkova and A.A. Turgaeva "Ways of Increasing Innovative Activity in the Agrarian Sphere as a Basis of Food Security", Overcoming Uncertainty of Institutional Environment as a Tool of Global Crisis Management, pp. 381-386, 2017. Available at: http://www.springer.com/gp/book/9783319606958\#otherversion=97833 19606965 